\title{
Eye Lens Weight as an Age Indicator in Yellow-necked Mice
}

Ciężar soczewki oka jako wskaźnik wieku u myszy leśnej

\author{
Leszek NABAGEO \& Karol PACHINGER
}

\begin{abstract}
Nabagło L. \& Pachinger K., 1979: Eye lens weight as an age indicator in yellow-necked mice. Acta theriol., 24, 11: 118-122 [With 3 Tables \& 1 Fig.]

Relations between age classes determined according to degree of wear of molars and eye lens weight were evaluated for Apodemus flavicollis (Melchior, 1834). Taking the eye lens as an indicator of age, it proved possible to distinguish age class which could not be determined by the tooth wear method. There was also a shift of individuals from age class III, determined on the basis of tooth wear, towards the older age classes. Increase in eye lens weigth in age classes was brought closer to the true age of individuals.

[Inst. Ecol., Polish Acad. Sci., 05-150 Dziekanów Leśny (LN); Inst. Zool., Comenius Univ., Šafarikovo nam. 6, 88545 Bratislava, Czechoslovakia (KP)].
\end{abstract}

\section{INTRODUCTION}

Studies made up to the present time have presented many formulas for determining the age of Apodemus flavicollis ( $\mathrm{Mel} \mathrm{ch}$ i o r, 1834) depending on the degree of wear of the molars (Felten, 1952; A d a m c z e w s ka, 1959; A d a m c z ews ka-A n d r z e je w s ka, 1967; $\mathrm{S}$ tein er, 1968). Degree of tooth wear depends not only on age, but also on the rodents' diet, and consequently estimated age may reflect the animals' true age with a varying degree of accuracy. It has been accepted in the case of many rodents that the best indicator of their age is the weight of dry eye lens mass, determined by L or d's method (1959). Growth curves for eye lens weight have been plotted for, inter alia, Clethrionomys (A s k n e r \& Hansson, 1967), Microtus arvalis (Martinet, 1966; A d a m c z ewska-Andrzejewska, 1972) and Apodemus agrarius (Adamczewska-Andrzejewska, 1973). This index would appear to depend to the least degree on the habitat conditions in which the rodents live.

An attempt has been made in the present study to establish the relations which exist between age classes determined by degree of molar wear in Apodemus flavicollis and weight of eye lens dry mass.

\section{MATERIAL AND METHODS}

The rodents were caught by means of snap traps in October 1976 in the Jurský šúr reserve near Bratysława. Material was collected from three habitats: 1. alder wood., 2. on the boundary between the alder wood and hay meadow, 3 . on the fringe of the Panonski copse (in which oak predominated), the hay meadow and a cultivated field. The study area and trapping methods have been described in detail by Pachinger \& Nabagło (1978). Fifty-six individuals of Apodemus flavicollis were used from among the rodents caught. After weighing the animals and measuring their body and tail lengths, they were dissected, the sexual activity of females determined and the eyes prepared, then kept in $10 \%$ formalin solution for two weeks, after which the lens were removed from them. The eye 
lens were dried at a temperature of $80^{\circ} \mathrm{C}$ for 48 hours, then both lens of each individual were weighed together with accuracy to $0.1 \mathrm{mg}$. In addition the rodents' age was estimated on the basis of degree of molar wear in accordance with the patterns given by Adamczewska (1959) and after Steiner (1968).

\section{RESULTS}

Calculation was made of the coefficients of correlation between age classes on the basis of tooth wear, body weight, length of body, tail

Table 1

Coefficients of linear correlation $(r)$. (critical value $r(\alpha=0.01, \mathrm{n}-1=55)=0.3541$ ).

\begin{tabular}{lccccc}
\hline & $\begin{array}{c}\text { Body } \\
\text { weight }\end{array}$ & $\begin{array}{c}\text { Body } \\
\text { length }\end{array}$ & $\begin{array}{c}\text { Tail } \\
\text { length }\end{array}$ & $\begin{array}{c}\text { Age classes } \\
\text { Adamczewska (1959) }\end{array}$ & $\begin{array}{c}\text { Age classes } \\
\text { Steiner (1968) }\end{array}$ \\
\hline Eye lens weight & 0.3818 & 0.3248 & 0.2828 & 0.7623 & 0.8019 \\
\hline
\end{tabular}

length and weight of eye lens dry mass (Table 1). The highest coefficients of correlation were obtained for the reciprocal relation between age classes and eye lens weight. Age classes determined after S t e i n e r (1968) and eye lens weight ( $r=0.8019$, Table 1$)$, were most closely correlated.

Equations of straight line regression were calculated for the correlation between age classes and eye lens weight:

1. age classes after A d a m c z e w s k a (1959):

$$
y=2.7311 x+9.3340
$$

2. age classes after $\mathrm{S}$ t e in e r (1968):

$$
y=2.2869 x+10.0208
$$

Table 2

Age structure of individuals caught on boundary between alder wood and meadow, estimated on basis of teeth after Adamczewska (1959), St e in er (1968) and eye lens weight in A. flavicollis.

Percentage of individuals in age classes
Age class Estimated on basic of Estimated on basis of eye teeth lens weight

$\mathrm{n} \% \mathrm{n} \quad \%$

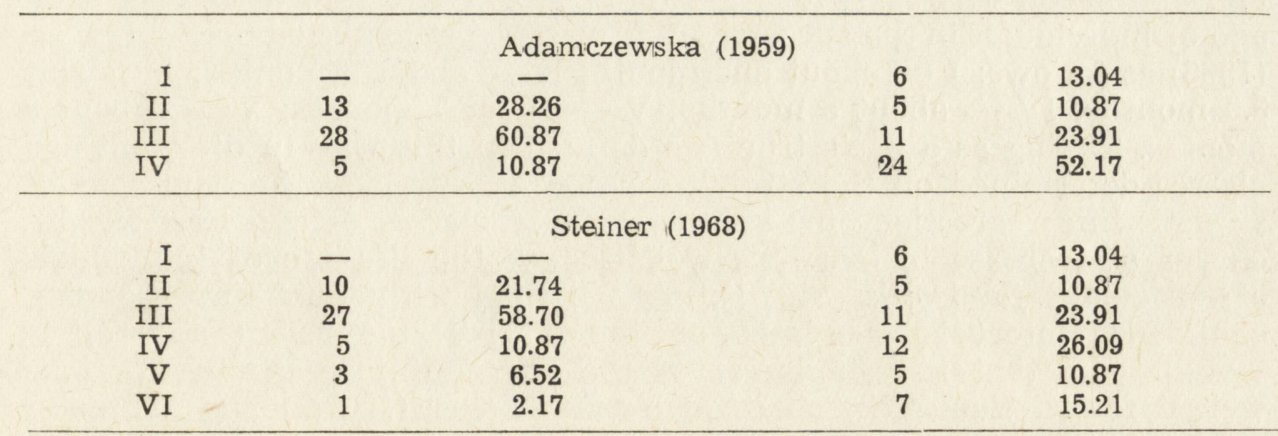


The age structure of individuals caught on the boundary between alder wood and hay meadow was calculated, using the established equations for straight line regressions, and comparing this structure with age structures calculated on the basis of degree of tooth wear after A da meze w ska (1959) and after Stein e (1968) (Table 2). Taking the weight of their eye lens as the index of the individuals' age, rodents aged about one month old were distinguished in the group examined, which it had proved impossible to distingulish when using the index of tooth wear. When defining age by means of eye lens weight it was also found that some of the individuals from age group II, distinguished on the basic of tooth wear, shifted in the direction of the older age classes (Table 2).

\section{DISCUSSION}

A d a m c z e w sk a (1959) stated that the age classes she distinguished on the strength of degree of molar wear in A. flavicollis correspond to the following true ages: I - about one month; II - about 2 months; III - about 5 months; IV - about 9 months. S t e in e r (1968) did not define true age in corresponding age classes, but gave the degree to which age classes distinguished by different authors coincide, also

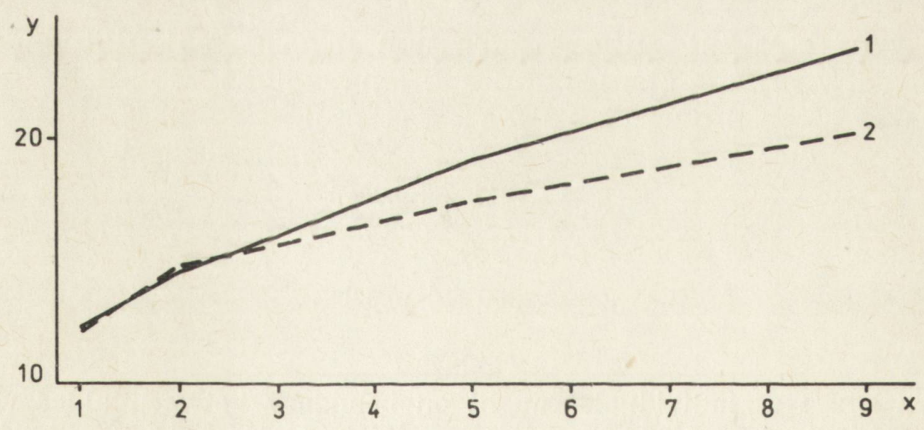

Fig. 1. Growth curves of eye lens weight in Apodemus flavicollis estimated on basis of age classes.

1 - after Steiner (1968); 2 - after A d a m cze w s ka (1959)

taking the study by A d a m c zewska (1959) into account. It would appear that on this basis it is possible approximately to define the true age of individuals in the successive age classes distinguished by $\mathrm{S} t \mathrm{e}$ i $\mathrm{n}$ e $\mathrm{r}$ (1968) as follows: I - about one month; II - about 2 months; III about 3.5 months; IV - about 5 months; V - about 7 months; VI - about 9 months. Taking as a basis true age defined in this way in different age classes determined on the strength of tooth wear, and the equations of straight line regressions for age classes and classes of eye lens weight, curves of increase in eye lens weight over the lifetime of individuals of Apodemus flavicollis (Fig. 1), were plotted with their corresponding confidence intervals calculated on the level $1-\alpha=0.95$ (Table 3 ). It would seem that the similarity of the curve of increase in eye lens weight for $A$. flavicollis, obtained by $\mathrm{S}$ te in e r (1968) using a greater 
number of classes in the same time interval, is more realistic than A d a m c z e w ska's age classes (1959). In both cases, however, the group of individuals belonging to age class I was distinguished on the basis of eye lens weight, but this class was not determined by the tooth wear method. It is somewhat difficult to find an explanation of this, as this category is distinguished on the basis of absence of the third molar $\left(M^{3}\right)$. It may be that this molar grows within a period of approximately one month. The existence of individuals of this age may be justified since out of 18 females dissected, postpartum maculae were found on the uterus of 6 . Differences in the numbers of individuals in the remaining age groups, determined on the basis of tooth and eye lens

Table 3

Confidence intervals on level $1-\alpha=0.95$ for growth curves of eye lens weight in $A$. flavicollis, calculated in relation to age classes estimated on basis of teeth after A d m czewska (1959) and Steiner (1968).

\begin{tabular}{|c|c|c|c|}
\hline Age class & $\begin{array}{l}\text { Approximate true } \\
\text { age (months) }\end{array}$ & $\begin{array}{l}\text { Eye lens weight } \\
\text { (mg) }\end{array}$ & $\begin{array}{l}\text { Confidence } \\
\text { interval }\end{array}$ \\
\hline \multicolumn{4}{|c|}{ Adamczewska (1959) } \\
\hline I & 1 & 12.06 & $9.82-14.31$ \\
\hline II & 2 & 14.80 & $13.17-16.42$ \\
\hline III & 5 & 17.53 & $16.29-18.76$ \\
\hline IV & 9 & 20.26 & $18.27-22.24$ \\
\hline \multicolumn{4}{|c|}{ Steiner (1968) } \\
\hline I & 1 & 12.31 & $10.17-14.45$ \\
\hline II & 2 & 14.59 & $13.30-15.88$ \\
\hline III & 3.5 & 16.88 & $16.02-17.75$ \\
\hline IV & 5 & 19.17 & $17.82-20.52$ \\
\hline $\mathrm{V}$ & 7 & 21.45 & $19.24-23.67$ \\
\hline VI & 9 & 23.74 & $20.59-26.90$ \\
\hline
\end{tabular}

weight, might have arisen as the result of differences in the food conditions of the individuals we studied and the individuals taken for defining tooth patterns.

To sum up, it would appear that by taking the weight of eye lens as an index of age it is possible in the case of Apodemus flavicollis also to obtain a fuller picture of the age structure of the population of this species.

\section{REFERENCES}

Adamczewska K. A., 1959: Untersuchungen über die Variabilität der Gelbhalsmaus, Apodemus flavicollis (M e l ch i o r, 1834). Acta theriol., 3, 10: 141-190 . Adamczewska-Andrzejewska K.A., 1967: Age reference model for Apodemus flavicollis (M elchior, 1834). Ekol. pol. A, 41: 787-790. A damczewska-Andrzejewska K.A., 1972: The lens weight as indicator of age in the wild Microtus arvalis population. Bull. Acad. Pol. Sci. Cl. II, 21, 5: 331-336. A d a mczewska-Andrzejewska K.A., 1973: Growth, variations and age criteria in Apodemus agrarius (Pallas, 1771). Acta theriol., 18, 19: 353-394. Askaner T. \& Hansson L., 1967: The eye lens as an indicator in small rodents. Oikos, 18: 151-153. Felt en H., 1952 Untersuchungen zur Ókologie und Morphologie der Waldmaus (Apodemus sylvaticus L.) und der Gelbhalsmaus 
Apodemus flavicollis (Melchior) im Rhein-Main-Gebiet. Bonn. Zool., Beitr., 3: 187-206. Lord R. D. Jr., 1959: The lens as an indicator of age in cottontail rabbits. J. Wildl. Mgmt., 23, 3: 358-360. M a r t in e t L., 1966: Determination de l'age chez le campagnol de champs (Microtus arvalis) par la pesce du cristalin. Mammalia, 30, 3: 425-430. P a ching e r K. \& $\mathrm{Nabag} 10$ L., 1978: Rozbor troch synúzií drobných zemných cicavcov z rezervácie Jurský šúr. Biológia (Bratislava), 33, 2: 133-140. S t e in er H. M., 1968: Untersuchungen über die Variabilität und Bionomie der Gattung Apodemus (Muridae, Mammalia) der Donau-Auen von Stockerau (Niederösterreich). Z. für wiss. Zool., 177: 1-96.

Accepted, September 28, 1978. 